\title{
Correction to: Growth and Movements of Mummichogs (Fundulus heteroclitus) Along Armored and Vegetated Estuarine Shorelines
}

\author{
Kevin P. Crum ${ }^{1,2} \cdot$ Richard G. Balouskus ${ }^{1,3} \cdot$ Timothy E. Targett ${ }^{1}$
}

Published online: 7 January 2019

(C) The Author(s) 2019

\section{Correction to: Estuaries and Coasts (2018) 41 (Suppl 1): S131-S143 https://doi.org/10.1007/s12237-017-0299-x}

The article Growth and Movements of Mummichogs (Fundulus heteroclitus) Along Armored and Vegetated Estuarine Shorelines, written by Kevin P. Crum, Richard G. Balouskus, and Timothy E. Targett, was originally published electronically on the publisher's internet portal (currently SpringerLink) on 31 August 2017 without open access.

With the author(s)' decision to opt for Open Choice the copyright of the article changed January 2019 to (C) The Author(s) 2019 and the article is forthwith distributed under the terms of the Creative Commons Attribution 4.0 International License (http://creativecommons.org/licenses/ by/4.0/), which permits use, duplication, adaptation,

distribution and reproduction in any medium or format, as long as you give appropriate credit to the original author(s) and the source, provide a link to the Creative Commons license and indicate if changes were made.

The original article has been corrected.

Open Access This article is distributed under the terms of the Creative Commons Attribution 4.0 International License (http:// creativecommons.org/licenses/by/4.0/), which permits use, duplication, adaptation, distribution and reproduction in any medium or format, as long as you give appropriate credit to the original author(s) and the source, provide a link to the Creative Commons license and indicate if changes were made.

The online version of the original article can be found at https://doi.org/ $10.1007 / \mathrm{s} 12237-017-0299-\mathrm{x}$

Kevin P. Crum

crumkev@gmail.com

1 School of Marine Science and Policy, University of Delaware, Lewes, DE 19958, USA

2 Present address: PreciseTarget, 7201 Wisconsin Avenue, Suite 650, Bethesda, MD 20815, USA

3 Present address: Inspire Environmental, 88 Silva Lane, Middletown, RI 02842, USA 